University of New Hampshire

University of New Hampshire Scholars' Repository

Psychology Scholarship

College of Liberal Arts (COLA)

3-1-2009

\title{
Personal intelligence expressed: A theoretical analysis
}

John D. Mayer

University of New Hampshire, Durham, jack.mayer@unh.edu

Follow this and additional works at: https://scholars.unh.edu/psych_facpub

Comments

CAPA, 2009. This paper is not the copy of record and may not exactly replicate the authoritative document published in the APA journal. Please do not copy or cite without author's permission. The final article is available, upon publication, at: https://dx.doi.org/10.1037/a0014229

\section{Recommended Citation}

Mayer, J. D. (2009). Personal intelligence expressed: A theoretical analysis. Review of General Psychology, $13,46-58$.

This Article is brought to you for free and open access by the College of Liberal Arts (COLA) at University of New Hampshire Scholars' Repository. It has been accepted for inclusion in Psychology Scholarship by an authorized administrator of University of New Hampshire Scholars' Repository. For more information, please contact Scholarly.Communication@unh.edu. 


\title{
RUNNING HEAD: PERSONAL INTELLIGENCE EXPRESSED
}

\section{Personal Intelligence Expressed: \\ A Theoretical Analysis}

\author{
John D. Mayer \\ University of New Hampshire
}

Prepublication version of:

Mayer, J. D. (2009). Personal intelligence expressed: A theoretical analysis. Review of General Psychology, 13, 46-58.

\section{Author Notes}

The author is very grateful to a number of people who read and commented on earlier drafts of this work: Marc A. Brackett, David R. Caruso, Mike Faber, Maia Hazelwood and Rich Wilson, and to the anonymous reviewers. I wish to extend my thanks to them all; the article is far stronger for their comments.

\section{Abstract}

An individual's cumulative life decisions help determine that person's well being. To make good decisions requires knowing something about who one is and who one wants to be. It seems plausible that personality may draw on a specifically-tailored intelligence that supports its own self-understanding and contributes to such life decisions. This personal intelligence (PI) helps the individual meet his or her own personal needs, and to fit in with (or stand out from) the environment. What are people high in personal intelligence actually like relative to those lower in the skills? Drawing on a 2008 theory of PI-related abilities, this article reviews several literatures to examine what features distinguish the behavior of people high in personal intelligence from those lower in such skills. The feature list sets the stage for future research in distinguishing high from low PI individuals according to their life expressions. 


\section{Personal Intelligence Expressed:}

\section{A Theoretical Analysis}

A person's cumulative life decisions are a key determinant of that individual's well being. Some people make excellent decisions regarding their relationships with others, their occupational success, their health, and their long-term happiness (Galotti, 2001). Others seem to make chance, chaotic, or even self-destructive choices (e.g., Pelham, Mirenberg, \& Jones, 2002; Sloan, 1983). Much of decision theory focuses on specific areas of choice, such as how a physician makes a diagnosis or how an investor places an economic bet (Ericsson, 2007). More global personal life choices - who one marries, where one works - are crucial as well.

Making good personal choices involves knowing something about who one is and who one wants to be (Higgins, 1987; Markus \& Nurius, 1986). Deciding whether to fit in or to stand out, for example, one must know something about one's own psychological preferences and make-up (Niedenthal, Cantor, \& Kihlstrom, 1985). There are, however, myriad sides to a person's psychology. Such personal complexities make fitting in with one's surroundings, standing out from them, or mixing such strategies, a challenging endeavor. The various sides of a person's psychology often are referred to, collectively, as an individual's personality.

Personality both characterizes a person's psychological shape - her psychological attributes and what is noticeable or not about her - and helps to shape that psychology. For example, an individual's personality will reflect whether she is more emotional than not, possesses an intellect that presides over her feelings, or vice versa, and will include the struggle between her basic urges and self control. In addition, personality governs and organizes those same motives and emotions, thoughts and intelligences, mental plans and actions. The choice of where to fit in or to stand out- and understanding how to do so - all are part of that governing personality system.

Personal life decisions depend in part on the intelligences the individual brings to bear on life choices. Intelligences refer to personality's capacity to carry out abstract reasoning in a valid, accurate manner (Carroll, 1993; Sternberg \& Detterman, 1986). Generally speaking, when an intelligence is higher, people make better choices. For example, those higher in verbal-propositional intelligence are likely to do better in contexts that require such thinking: they complete more years of schooling, obtain higher grades, and enter into higher-prestige occupations than others (Matarazzo, 1972; Wechsler, 1997). Those high in emotional intelligence have better social relations than others (Mayer, Roberts, \& Barsade, 2008). Those high in spatial intelligence may find their ways into such occupations as architecture, which can utilize such skills well (Lubinski, Webb, \& Morelock, 2001).

It seems plausible that personality draws on an intelligence that supports its own self-understanding and contributes to making life decisions. Such an intelligence, referred to here as personal intelligence, can be viewed as a capacity to reason about one's own and others' personalities and personal information, and to use such personal information to assist thought. In a recent article, a theory of PI was developed, dividing it into areas of (a) recognizing personality-relevant information, (b) synthesizing such information into one's mental models of the self and others, (c) guiding choices with such information, and (d) systematizing one's own goals, plans, and life stories. Next, that earlier article outlined a plan for assessing PI through ability testing (Mayer, 2008). The 
article left open, however, how PI might be expressed by an individual and how such expressions might be recognized.

A person's expression of an intelligence is different from his or her inner ability at problem solving. Expressing a specific intelligence such as personal intelligence ought to yield a set of distinct behavioral signatures (Cervone, 2005; Mischel, 2004). To track down PI's expressions, this article will review scientific literature relevant to the manifestations of PI in an individual's life. The identification of such expressions in a person's context, biography, and creative products will be considered. In other words, this article focuses on the question: "What does the expression of PI look like?"

After this introduction, the second portion of the article, "Personal Intelligence and Its Significance" provides a précis of PI's significance, the reasons for its neglect todate, how PI compares to other intelligences, and the rationale for studying its expression. The third section, "Personal Intelligence Expressed: A Review of Key Characteristics" will draw, first, on such precursor concepts to PI as those of psychological mindedness and intrapersonal intelligence. It will examine how the expression of such qualities has been characterized in the past. The review then will turn to the specific abilities that may make up PI, and the expressions each gives rise to. These abilities include areas such as self-knowledge of one's abilities, being a "good judge" (of other people), and personal goal management (e.g., Dunning, 2005; Funder, 1999). Describing the expressions of PI is key to future research because understanding such expressions form the basis for procedures such as coding systems to identify those who are high or low in PI from interviews or biographies. The concluding "Discussion" section will include a summary of the present theoretical work, a further examination of its significance, and a view of future empirical work.

\section{PERSONAL INTELLIGENCE AND ITS SIGNIFICANCE}

\section{Personal Intelligence: A Précis}

People who understand their own and others' personalities may live more successfully with others than those who lack such understanding (Baron-Cohen, 1995; Buss, 1991, 2001). The social brain hypothesis contends that, roughly two million years ago, the size of the human brain increased in part to support such interpersonal understanding. More specifically, evolutionary selection favored people with larger brain capacities because such individuals could, for example, better judge one another and live cooperatively in early societies (Dunbar, 2003). For example, choosing a skilled hunting

partner was a potentially life-or-death decision, and choosing a mate successfully ensured one's genetic continuity (Buss, 1991).

The ability to understand one's own and others' personalities remains relevant today. Better self-understanding may assist a person to meet organizational demands for specialization, for example, by promoting a closer person-occupational fit (e.g., Holland \& Holland, 1978); it may assist one's judgment in selecting a life partner; it also may assist, more generally, meeting what seems to be society's increasing demands for personal self control, and fulfilling the psychosocial contract that exists between each person and society.

The Study of Personal Intelligence: Neglect and Delay 
It is initially surprising that $20^{\text {th }}$ century researchers largely neglected the concept of personal intelligence - despite the fact that the term was in occasional use at least since the 1850s (e.g., Anonymous, February 27, 1851; Guernsey, July 1857). Several commonly held beliefs of the $20^{\text {th }}$ century may account for this neglect. First, researchers frequently viewed the personality system as exerting an often weak or irrelevant influence on people's lives (Cunningham, 2005; Kenrick \& Funder, 1988; Mischel, 1968).

Second, individual difference researchers preferred to focus on "cool" as opposed to "hot" intelligences in the early-to-mid $20^{\text {th }}$ century. Cool intelligences concern reasoning with relatively impersonal material such as word meanings and visual patterns and include the verbal and perceptual-organizational intelligences. The hot intelligences, by contrast, concern reasoning with more personally-relevant information such as one's social status and self-esteem, and include the social and emotional intelligences. Although cool intelligences predicted many educational outcomes of importance, social intelligence (the first-studied among the hot intelligences) yielded less interesting results; research into the hot intelligences declined as a consequence (Walker \& Foley, 1973).

Third, personal intelligence might have connoted a sort of "Generation Me" ethos because of its focus on the self (Twenge, 2006). Although many social and educational practices encourage self-focus and the development of self-esteem, a number of theorists expressed grave reservations as to the wisdom of such practices, seeing in them the potential for increased narcissism and social divisiveness (Baumeister, Campbell, \& Krueger, 2003). Researchers who harbored such reservations might have avoided studying personal intelligence, which could have seemed associated, at least superficially, with the self-esteem ethos (cf., Kincaid, 2002). A related reaction might be that PI was of interest primarily to elites who possessed sufficient economic and social freedom for self exploration. Considering questions such as whether personality matters and "Generation Me" issues can address whether personal intelligence deserves attention.

In fact, most recent scientific perspectives are more receptive to the study of PI. For example, late $20^{\text {th }}$ century views increasingly recognized the personality system as a key contributor to important life outcomes (e.g., Roberts, Kuncel, Shiner, Caspi, \& Goldberg, 2007). During that same time period, research into hot intelligences was reestablished and more promising results arose than before, particularly for emotional intelligence (e.g., Mayer et al., 2008). As noted already, some segments of society may equate a "Generation Me" outlook with problematic egotism and a consequent loss of social cohesion. It seems likely, however, that PI would moderate such egotism because the intelligence promotes accurate self-knowledge.

Finally, the related concern over elitism could be leveled at any intelligence. Broadening the list of intelligences (where justified), however, tends to democratize them by acknowledging the broader number of mental abilities that exist, relative to past conceptions, and the variety of individuals who possess them. Moreover, because personal intelligence may help people satisfy both their own needs and contribute more generally to society, everyone may benefit as a consequence.

The Scope and Definition of Personal Intelligence Converging Concepts of Personality

An individual's personality can be thought of as a master psychological system responsible, in part, for the operation of its parts - its motives, emotions, thoughts, self- 
control, and social acts. A number of recent articles outline some of the generally accepted thinking about personality (Buss, 2001; Funder, 2006; Mayer, 2005; McAdams \& Pals, 2006; McCrae \& Costa, 1999; Roberts et al., 2007). The consistencies across these frameworks and perspectives are considerable.

These consistencies include, briefly, first, that personality exists "inside the skin" - internally - with many private internal conscious and automatic feelings and thoughts; and that personality interacts with the outside world. Second, contemporary views agree that personality exhibits a group of consistent features that are expressed in a relatively stable fashion, including traits such as extraversion, intelligence, and conscientiousness. Third, personality can observe itself, and observe and model others' personalities as well. From this, an individual develops models of what different people are like and how to predict their behaviors. Finally, personality develops in important ways over time.

Such ideas generate a relatively clear basis for understanding what a personal intelligence might involve. Specifically, PI involves the capacities:

(a) to recognize personally-relevant information from introspection and from observing oneself and others, (b) to form that information into accurate models of one's own and others' personalities, (c) to guide one's choices by using personality information where relevant, and (d) to systematize one's goals, plans, and life stories for good outcomes (Mayer, 2008, p. 215).

\section{Distinguishing a Personal Intelligence}

Personal intelligence can be plainly distinguished from other hot intelligences such as the emotional and social. Some of the characteristics of these hot intelligences are compared in Table 1. For example, emotional intelligence is defined as the capacity to reason about emotions and emotional knowledge and to use emotions to enhance thought (Column 1, Row 1). EI is often divided further into such areas as the accurate perceiving of emotion, using of emotions to enhance thought, understanding emotions, and managing them (Row 3). EI reasoning extends to emotional reasoning both about the individual and society; as such, it is part of both personal and social intelligence. EI's specific focus on emotions, however, renders it more focused than the more general personal and social intelligences (Mayer, Salovey, \& Caruso, 2008).

Shifting the focus to personal intelligence itself, PI addresses not only an individual's understanding of emotions, but also of his or her motives, self-concepts, dreams, imaginings, and other internal experiences and mental models of the self and others (Column 2, Row 2).

Personal intelligence is different as well from (but complementary to) social intelligence. PI focuses on inner personal experience and personal information in oneself and others: one's own and others' inner states and motives, traits, personal goals, and life stories. By contrast, social intelligence is relatively outer directed and involves reasoning about situations, interactions, social skills, and the interactions among groups (Table 1, column 3).

Personal intelligence also differs from self-knowledge. Personal intelligence explicitly includes the abilities to reason about information sources relevant to personality and to reason about one's personal goals and plans. Self-knowledge, by contrast, describes the state of having acquired a relatively accurate picture of one's own characteristics. Personal intelligence implies such accurate self-knowledge, but 
additionally includes the abilities, for example, to form accurate models of others' personalities, and to use personal information in making decisions and achieving goals.

Table 1: A Comparison of Three Hot Intelligences

\begin{tabular}{|c|c|c|c|}
\hline \multirow[t]{2}{*}{ Features } & \multicolumn{3}{|c|}{ Sample Hot Intelligences } \\
\hline & Emotional Intelligence & Personal Intelligence & Social Intelligence \\
\hline $\begin{array}{l}\text { Key } \\
\text { Description } \\
\text { of Capacities }\end{array}$ & $\begin{array}{l}\text { To reason about emotions } \\
\text { and emotional knowledge } \\
\text { and to use emotions to } \\
\text { enhance thought (e.g., Mayer } \\
\text { et al., 2008) }\end{array}$ & $\begin{array}{l}\text { To reason about personal } \\
\text { information and } \\
\text { personality and to use } \\
\text { such information to } \\
\text { enhance thought }\end{array}$ & $\begin{array}{l}\text { To reason about the } \\
\text { individual in relation } \\
\text { with others and other } \\
\text { groups, and to use } \\
\text { such information to } \\
\text { enhance thought }\end{array}$ \\
\hline $\begin{array}{l}\text { Key Target } \\
\text { Information }\end{array}$ & $\begin{array}{l}\text { Emotional expressions, } \\
\text { emotional changes in the } \\
\text { body, emotional feelings, } \\
\text { emotional meanings }\end{array}$ & $\begin{array}{l}\text { Internal states, motives, } \\
\text { goals, emotions, traits } \\
\text { such as extraversion, } \\
\text { intelligence, and outside } \\
\text { information about } \\
\text { oneself }\end{array}$ & $\begin{array}{l}\text { Meanings of situations } \\
\text { of social interactions, } \\
\text { rules of social } \\
\text { interaction, } \\
\text { motivational and } \\
\text { emotional states and } \\
\text { pressures emerging } \\
\text { from social groups }\end{array}$ \\
\hline Key Abilities & $\begin{array}{l}\text { - Perceive emotions in the } \\
\text { self and others } \\
\text { - Use emotions to enhance } \\
\text { thought } \\
\text { - Understand emotions and } \\
\text { emotional meanings } \\
\text { - Manage emotions in the } \\
\text { self and others }\end{array}$ & $\begin{array}{l}\text { - Recognize personally- } \\
\text { relevant information } \\
\text { from introspection and } \\
\text { from observing oneself } \\
\text { and others } \\
\text { - To form information } \\
\text { into accurate models of } \\
\text { personality } \\
\text { - To guide one's choices } \\
\text { by using personally- } \\
\text { relevant information, } \\
\text { - To systematize one's } \\
\text { goals, plans and life } \\
\text { stories }\end{array}$ & $\begin{array}{l}\text { - Perceive and } \\
\text { remember social } \\
\text { situations } \\
\text { - Act with social skill } \\
\text { - Influence other } \\
\text { people effectively } \\
\text { within situations } \\
\text { - Understand and } \\
\text { interpret situations } \\
\text { - Understand how } \\
\text { situations follow one } \\
\text { another } \\
\text { - Undertand } \\
\text { interrelations among } \\
\text { groups }\end{array}$ \\
\hline $\begin{array}{l}\text { Key } \\
\text { References }\end{array}$ & $\begin{array}{l}\text { Salovey \& Mayer (1990); } \\
\text { Mayer et al. (2008) }\end{array}$ & $\begin{array}{l}\text { Gardner (1990); Mayer } \\
\text { (2008) }\end{array}$ & $\begin{array}{l}\text { Thorndike (1920); } \\
\text { Weis \& Süß (2007) }\end{array}$ \\
\hline
\end{tabular}

Personal intelligence, in other words, occupies a distinct and unique position among hot intelligences (and in relation to concepts such as self-knowledge). The significance of PI to the individual, coupled with the unique set of mental abilities it includes, provides a reasonable basis for its continued theoretical development.

Assessing the Expression of Personal Intelligence:

The Whys and Wherefores

Internal Abilities versus External Expression

Most psychologists draw a distinction between the internal mental capacities that make up an intelligence, on the one hand, and the person's expressions of the intelligence in the environment, on the other. Internal mental abilities are the problem-solving capacities that define the intelligence itself. The gold standard for the measurement of 
such skills is mental-ability testing - the use of a test to ask individuals to solve problems, and to then compare those answers against a standard of correctness (Carroll, 1993; Mayer et al., 2008).

The expression of an intelligence, on the other hand, reflects the manner in which a person uses his or her intelligence in the world. In many cases, the expression of an intelligence can reflect the person's level of intelligence fairly directly. For example, one would expect people high in an ability to use it effectively, and those low in the ability to exhibit its absence. In other cases, however, a person who possesses an intelligence might choose not to employ it for motivational or social reasons. For example, women with high levels of mental abilities nonetheless may avoid careers in the physical sciences because of their greater interest in people or, alternatively, due to a lack of institutional support on the part of universities that train them (Ceci \& Williams, 2007). In other cases individuals may possess qualities that could be mistaken for an intelligence - for example, exhibiting attributes such as decisiveness, curiosity, and verbal skills that sometimes are mistaken for verbal intelligence (Perkins, Tishman, Ritchhart, Donis, \& Andrade, 2000). Perceptions of what make up an intelligence also may vary by culture (Sternberg, 2007). An intelligence (as a set of mental abilities) versus the expression of the intelligence, then, are two related but distinct qualities. The rationale for studying the expression of an intelligence is further developed next.

Why Should the Expression of an Intelligence Be Studied?

Studying the expression of intelligence is important for several reasons. First, carefully analyzing the expression of an intelligence may reveal previously-overlooked mental abilities that make it up. For example, an analysis of people's intellectual selfmanagement indicates that certain abilities such as inhibiting one's incorrect ideas may be a key part of intelligence that could be added to present-day intelligence tests (Friedman et al., 2006).

Secondly, understanding how a person expresses an intelligence has to do with how a person is perceived socially by others. Does the person freely express his or her intelligence in a given area, or do such expressions make others uncomfortable (and therefore, does the person suppress them)? Such findings are important to understanding individual and group relationships.

A bit more broadly, measuring an intelligence's expression indicates something about its contributions to an individual's success at various endeavors. Outlining the advantages the intelligence might bring to a person has practical implications regarding how someone with the mental ability might best use it, and how others with less of it might strengthen their problem solving in the area.

Measuring the expression of intelligence is important, therefore, to gauging whether the key aspects of the mental-ability are being measured, as well as to understanding how a person is perceived, and to discovering the significance of the intelligence to a person's life endeavors.

The Ease of Measuring Expression Varies by Intelligence

Some intelligences are expressed in ways that are easier to measure than others. Generally speaking, an intelligence that is broad, clearly defined, and operates relatively discretely - such as verbal intelligence - should be expressed relatively clearly. An intelligence that is, by contrast, more narrowly defined and often embedded in broader decision making, may be harder to assess on its own. An example of a more difficult-to- 
gauge "embedded" intelligence is emotional intelligence. Emotional reasoning is so embedded amid other considerations (such as rationality) in most to-be-solved problems, that understanding its unique expression is difficult to disentangle in terms of the individual's expressions. To be sure, EI contributes to important life outcomes, but its individual manifestations often are difficult to perceive without using ability testing as a marker (Mayer et al., 2008).

Personal intelligence, on the other hand, operates in a relatively holistic fashion on a person's total life expression. For that reason, its expression should be reflected in the sophistication of an individual's overall goals, behaviors, and life development (Funder, 2006; Mayer, 2005; McAdams \& Pals, 2006). Tracking the expression of personal intelligence ought to be both possible and key to its understanding. The expression of personal intelligence may be manifest in such everyday expressions as a person's interactions with others or career functioning. Coding PI in a person's creative products might be possible as well, for example, by examining the campaign activities of US presidential candidates or the works of television writers. Coding personal intelligence for one or more portions of a person's life may allow for crucial predictions of the individual's strengths and weaknesses.

Many precedents for successfully coding the expression of personality characteristics already exist (Song \& Simonton, 2007). For example, Winter (2005) coded US presidents' inaugural addresses so as to chart their motivational profiles, and coded similar materials of English royalty and other leaders. From such motivational coding, Winter has successfully predicted a number of key aspects of the leaders' behaviors including, for example, their likelihood to start wars (Winter, 2005). Porter and Suedfeld (1981) have coded literary figures' integrative complexity to examine how wartime stress reduces, and peace promotes, certain kinds of thinking. To provide the best possible basis for coding PI, it is necessary first to carefully demarcate how PI might be expressed.

\section{PERSONAL INTELLIGENCE EXPRESSED: A REVIEW OF KEY CHARACTERISTICS}

\section{Plan of Approach}

To develop the best possible understanding of the expression of personal intelligence, a review was undertaken of key theoretical and empirical research relevant to PI's expression. The first part of the review examines individuals defined as high and low in two precursor-concepts to personal intelligence: psychological mindedness (as an ability), and intrapersonal intelligence - one of Gardner's (1983) multiple intelligences. The second part of the review draws on descriptions of individuals high and low on the skills that more specifically make up the four areas of PI as defined here; briefly: recognizing personally-relevant information, forming it into models, guiding one's choices, and systematizing life goals and stories (Mayer, 2008). For each specific area, between two and three representative and (relatively) well-developed research literatures were selected for inclusion.

The review will assemble a feature list of characteristics of people high and low in PI. Because each existing research area informs personal intelligence in a different way, the review will draw together the best ideas from many relevant areas for the first time. 
Moreover, the process of combining descriptions across relevant areas is likely to emphasize the more reliable findings regarding the construct to the extent that the skills overlap. The final feature list, therefore, is likely to contain ideas in which some confidence can be placed.

\section{Descriptions of People High and Low in Precursor Concepts Related to Personal Intelligence Psychological Mindedness}

At least two research areas can be regarded as precursors to personal intelligence, generally considered. The term psychological mindedness (PM) was introduced by researchers at the Menninger Clinic in the 1940s and 1950s to describe individuals who were better able than others to learn about themselves in psychotherapy, and to change. (The researchers were studying patient variables that might lead to a positive response to psychotherapy). The Menninger Clinic definition of PM has been summarized as:

A person's ability to see relationships among thoughts, feelings, and actions, with the goal of learning the meanings and causes of his experiences and behaviour (Appelbaum, 1973, p. 36).

A person high in such abilities exhibits an interest in others and what motivates them, and an orientation that includes a focus on future life planning (Appelbaum, 1973, p. 36).

Patients high in PM could learn about themselves and change more readily than others. Moreover, psychological mindedness was viewed as a characteristic of psychotherapists as an occupational group (Farber \& Golden, 1997), with prominent therapists, such as Sigmund Freud, singled out as high in PM (Appelbaum, 1973, p. 36). Some of the characteristics of ability-based psychological mindedness are summarized in the first row of Table 2. Later, the research emphasis in psychological mindedness shifted from a focus on ability to self-report-style measures of interest in psychological processes (see McCallum \& Piper, 1997, for a discussion) which no longer led to definitions or measures relevant to the treatment here (see Carroll, 1993; Mayer et al., 2008 for a discussion of self-report measures in relation to intelligence). 
Table 2: Summary of Key Expressions of High and Low Personal Intelligence (PI)

\begin{tabular}{|c|c|c|c|}
\hline \multirow[t]{2}{*}{ Concept Name } & \multirow[t]{2}{*}{ Core Abilities } & \multicolumn{2}{|c|}{$\begin{array}{c}\text { Key Expressions, Signs, and Indicators of } \\
\text { Personal Intelligence }\end{array}$} \\
\hline & & High PI & Low PI \\
\hline \multicolumn{4}{|c|}{ Precursor Concepts } \\
\hline $\begin{array}{l}\text { Psychological } \\
\text { mindedness (e.g., } \\
\text { Appelbaum, 1973) }\end{array}$ & $\begin{array}{l}\text { - Understands } \\
\text { relationships among } \\
\text { internal experiences } \\
\text { - Learns about meanings } \\
\text { and causes of behavior }\end{array}$ & $\begin{array}{l}\text { - Succeeds in/ benefits } \\
\text { from insight-oriented } \\
\text { psychotherapy } \\
\text { - Chooses psychotherapy } \\
\text { as an occupation } \\
\text { - Interested in psychology }\end{array}$ & $\begin{array}{l}\text { - Denies importance of } \\
\text { insight } \\
\text { - Avoids or fails at } \\
\text { psychotherapy } \\
\text { - Uninterested in mental } \\
\text { processes }\end{array}$ \\
\hline $\begin{array}{l}\text { Intrapersonal } \\
\text { intelligence (e.g., } \\
\text { Gardner, 1993) }\end{array}$ & $\begin{array}{l}\text { - Accesses and } \\
\text { symbolizes one's feeling } \\
\text { life } \\
\text { - Develops a highly } \\
\text { refined sense of self }\end{array}$ & $\begin{array}{l}\text { - Discusses feeling life } \\
\text { with insight } \\
\text { - Communicates clear } \\
\text { sense of personal identity, } \\
\text { be it as an independent } \\
\text { actor, or as leading member } \\
\text { of a group }\end{array}$ & $\begin{array}{l}\text { - Fails to distinguish } \\
\text { among internal states; } \\
\text { - Confused about or fails } \\
\text { to develop clear sense of } \\
\text { self }\end{array}$ \\
\hline \multicolumn{4}{|c|}{ Specific Ability Areas } \\
\hline \multicolumn{4}{|c|}{ 1. Recognizing Personality-Relevant Information } \\
\hline $\begin{array}{l}\text { Accurate emotional } \\
\text { perception (Mayer et } \\
\text { al., 2008) }\end{array}$ & $\begin{array}{l}\text { - Accurately perceives } \\
\text { emotions in the self and } \\
\text { others (e.g., in others' } \\
\text { faces and postures) }\end{array}$ & $\begin{array}{l}\text { - Negotiates well with } \\
\text { others } \\
\text { - Inspires others } \\
\text { - Good well-being }\end{array}$ & $\begin{array}{l}\text { - Engages in arguments, } \\
\text { conflict, and fighting } \\
\text { - Evidence of depression }\end{array}$ \\
\hline $\begin{array}{l}\text { Self-knowledge of } \\
\text { others' beliefs about } \\
\text { you (Oltmanns \& } \\
\text { Turkheimer, 2006) }\end{array}$ & $\begin{array}{l}\text { - Coordinates one's own } \\
\text { self-concept with the } \\
\text { perceptions of others }\end{array}$ & $\begin{array}{l}\text { - At times may exhibit low } \\
\text { energy or fatigue } \\
\text { - At times may exhibit low } \\
\text { self-esteem } \\
\text { - At times may feel } \\
\text { hopeless } \\
\text { - At times may experience } \\
\text { an unstable sense of self }\end{array}$ & $\begin{array}{l}\text { - Expresses a grandiose } \\
\text { sense of self-importance } \\
\text { - Believes he or she is } \\
\text { special, unique, and high } \\
\text { status } \\
\text { - Takes advantage of } \\
\text { others to achieve own ends } \\
\text { - Suspects, without basis, } \\
\text { that others are harming } \\
\text { them } \\
\text { - Reads hidden, } \\
\text { demeaning, or threatening } \\
\text { meanings in remarks or } \\
\text { events } \\
\text { - Perceives attacks on } \\
\text { character not apparent to } \\
\text { others }\end{array}$ \\
\hline $\begin{array}{l}\text { "Good judge" of } \\
\text { personality (e.g., } \\
\text { Funder, 1995) }\end{array}$ & $\begin{array}{l}\text { - Accurately identifies/ } \\
\text { assesses others' traits }\end{array}$ & $\begin{array}{l}\text { - Motivation to know } \\
\text { others } \\
\text { - Experienced with others; } \\
\text { extraverted }\end{array}$ & $\begin{array}{l}\text { - Uninterested in knowing } \\
\text { or understanding others }\end{array}$ \\
\hline \multicolumn{4}{|c|}{ 2. Forming Accurate Models of Personality } \\
\hline $\begin{array}{l}\text { Self-Knowledge of } \\
\text { Ability (e.g., Dunning, } \\
\text { 2005) }\end{array}$ & $\begin{array}{l}\text { - Accurately evaluates } \\
\text { one's own abilities, even } \\
\text { given ambiguous } \\
\text { feedback }\end{array}$ & $\begin{array}{l}\text { - Exhibits expertise in } \\
\text { areas claims expert } \\
\text { knowledge } \\
\text { • Seeks feedback via non- } \\
\text { biasing questions (e.g., } \\
\text { "How can I improve?"); }\end{array}$ & $\begin{array}{l}\text { - Overestimates expertise } \\
\text { in an area, or misjudges } \\
\text { interpersonal qualities } \\
\text { - Seeks feedback via } \\
\text { biasing questions of others } \\
\text { (e.g., "I'm good at this, }\end{array}$ \\
\hline
\end{tabular}




\begin{tabular}{l|l|l|} 
& $\begin{array}{l}\bullet \text { Self-corrects estimates } \\
\text { (e.g., of how much time } \\
\text { something will take) }\end{array}$ \\
\hline $\begin{array}{l}\text { The "Good actor" } \\
\text { (e.g., Wilson, 2002) }\end{array}$ & $\begin{array}{l}\bullet \text { "Inhabits" other's minds } \\
\text { and manners so as to } \\
\text { portray them accurately in } \\
\text { acting, writing, and other } \\
\text { arts } \\
\text { and their motives } \\
\bullet \text { Carefully observes the } \\
\text { mannerisms and } \\
\text { expressions of others } \\
\bullet \text { Uses writing as a method } \\
\text { of meaning-making about } \\
\text { one's life. }\end{array}$ \\
\hline
\end{tabular}

aren't I?" or "I'm a bad friend, aren't I?")

- Lacks empathic understanding of others

- Takes little notice of other's manners or expressions

- Extracts little or no meaning from one's life.

Matching personality
to the environment
(e.g., Niedenthal et al.,
1985)
1985)

\section{Guiding Choices with Accurate Personal Information}

- Tailors choices so as to $\quad \bullet$ Exhibits a good fit match, where useful, one's personality to the demands and opportunities of environments such as careers and housing

\begin{tabular}{l} 
\\
\hline Standing out from the \\
context when desirable \\
(e.g., Hackley \& \\
Kover, 2007)
\end{tabular}

- Stands out from the group so to protect one's own identity and closelyheld values and that of their spouse or between their personality and occupation

- Exhibits a good fit between their personality significant other

- Fits well into other smaller areas (e.g, geographic location) - Distinguishes viewpoints in conflict with the situation when the situation compromises personal identity and values

- Appreciates the length required of crucial life-span tasks such as developing expertise in an area or the time needed to get to know someone, or to find a life partner
- Exhibits a poor fit between their personality and occupation,

- Exhibits a poor fit between their personality and that of their spouse or significant other

- Fits poorly into other, smaller areas of choice (e.g, geographic location) - Fails to recognize when identity and personal values are contradicted or threatened in a given context

-Fails to recognize when it is important to express one's identity and values - Expresses erroneous beliefs about the time it might take to accomplish key life goals and tasks

\begin{tabular}{|c|c|c|c|}
\hline \multicolumn{4}{|c|}{ 4. Systematizing Goals, Plans, and Life Stories } \\
\hline $\begin{array}{l}\text { Systematized } \\
\text { Motivation (Emmons } \\
\text { \& King, 1988) }\end{array}$ & $\begin{array}{l}\text { - Creates a system of } \\
\text { goals that are mostly } \\
\text { coherent and compatible } \\
\text { with one another }\end{array}$ & $\begin{array}{l}\text { - Exhibits goals that are } \\
\text { well chosen and mostly } \\
\text { consistent with each other } \\
\text { (or, at least, not in } \\
\text { considerable conflict) }\end{array}$ & $\begin{array}{l}\text { - Exhibits goals that often } \\
\text { are inconsistent or } \\
\text { potentially in conflict with } \\
\text { one another, or that are } \\
\text { poorly chosen }\end{array}$ \\
\hline $\begin{array}{l}\text { Self-defining } \\
\text { memories (e.g., } \\
\text { Pillemer, 2003) }\end{array}$ & $\begin{array}{l}\text { - Motivates and guides } \\
\text { oneself by drawing on } \\
\text { meaningful and relevant } \\
\text { autobiographical } \\
\text { memories }\end{array}$ & $\begin{array}{l}\text { - Draws on memories of } \\
\text { the past to motivate } \\
\text { themselves now } \\
\text { - Uses autobiographical } \\
\text { information to hone their } \\
\text { self-definition }\end{array}$ & $\begin{array}{l}\text { - Neglects } \\
\text { autobiographical } \\
\text { memories } \bullet \text { Neglects } \\
\text { drawing upon personal } \\
\text { memories for any purpose }\end{array}$ \\
\hline $\begin{array}{l}\text { Making meaning from } \\
\text { autobiographies } \\
\text { (e.g., Erikson, 1963; } \\
\text { McAdams, 2006) }\end{array}$ & $\begin{array}{l}\text { - Understands life events } \\
\text { as part of a broader } \\
\text { pattern of self-acceptance, } \\
\text { uniqueness, meaning, and } \\
\text { service to others }\end{array}$ & $\begin{array}{l}\text { - Perceives tasks and goals } \\
\text { as part of a meaningful, } \\
\text { generative activity }\end{array}$ & $\begin{array}{l}\text { - Interprets autobiography } \\
\text { in destructive, hopeless or } \\
\text { blaming fashions } \\
\text { - Fails to express positive } \\
\text { senses of life experiences }\end{array}$ \\
\hline
\end{tabular}




\section{Intrapersonal Intelligence}

Gardner's (1983) formulation of multiple intelligences included a pair of intraand inter-personal intelligences, which he referred to together as personal intelligences. Intrapersonal intelligence corresponded in part to emotional intelligence; it had at its core "access to one's feeling life - one's range of affect and emotion" (Gardner, 1993, p. 239); that same intelligence also emphasized the capacity to develop a highly differentiated self (Gardner, 1983, p. 239), which corresponds to one part of personal intelligence as developed here. Gardner's second member of the pair, interpersonal intelligence, also contained aspects of personal intelligence (e.g., evaluating others' motives and intentions) but emphasized other skills more classically associated with social intelligence such as manipulating situations and motivating groups (Gardner, 1993, pp. $239,253)$.

In describing what intrapersonal intelligence - arguably the more relevant of the two - might look like, Gardner wondered whether it might best be described by, "a self that is highly developed and fully differentiated from others..." or, alternatively, by a "...a collection of relatively diverse masks...each of which is simply called into service as needed..." (Gardner, 1993, p. 252). Gardner's mention of relatively diverse masks may imply that high PI individuals can take on diverse social roles as needed. That and other key expressions of intrapersonal intelligence, as Gardner viewed them, are summarized in Row 2 of Table 2.

\section{Description of People High and Low in Specific PI Skills Recognizing Personality-Relevant Information}

Turning now to descriptions of people high and low in specific skills of PI, recall that PI's first broad skill area concerns recognizing personality-relevant information. Such information arises through introspection, through examining one's own and others' personalities, and through discovering others' opinion of oneself.

Recognizing Information about Internal States: The Instance of Accurate Emotional Perception

The capacity to introspect generally about one's internal states is a key aspect of personal intelligence. Accurate introspection includes the abilities to identify a range of internal experiences: motivational urges, emotional states, alterations in consciousness related to sleep, illness, and psychoactive substances, and to recognize the operation of such partially conscious defenses as suppression.

Studies of emotional intelligence and its specific areas provide some information about those able to accurately recognize and identify at least one class of such internal experience - the emotions (Salovey \& Grewal, 2005). For example, one group of tests measure accurate perception of emotions in faces, postures, and movements (e.g., Matsumoto, LeRoux, \& Wilson-Cohn, 2000; Nowicki \& Carton, 1993). A meta-analysis of such scales concluded that accurate emotional perception predicts a modest but significant rise in workplace effectiveness in professionals as diverse as physicians, human service workers, school teachers and principals, and business managers (Elfenbein, Der Foo, White, \& Tan, 2007). In part, such individuals may be better at fact-finding and prioritizing problems, as well as being better negotiators, and inspirers of others (Matsumoto, LeRoux, Bernhard, \& Gray, 2004; Rubin, Munz, \& Bommer, 2005). 
Such emotional accuracy also correlates inversely with depression, $r=-0.42$, and predicts well-being at approximately an $r=.55$ level (Carton, Kessler, \& Pape, 1999). These qualities are summarized in the emotional perception row of Table 2. Recognizing Self-Information from Others' Perceptions

Another aspect of accurate self-perception is recognizing others' views of oneself - a very challenging task, judging by the generally modest agreement between the self's and others' perceptions. One recent series of studies examined the self-awareness of those with symptoms of psychiatric disturbances in otherwise normal samples of military service personnel and college students. Individuals with disorders related to negative affect such as obessessive-compulsive personality disorder, cyclothymia, and dysthymia generally knew that others perceived them as obsessive, depressed, or anxious. On the other hand, those with paranoid, narcissistic and antisocial disorders often did not realize how others saw them. For example, paranoid individuals often realized they were angry but didn't realize others viewed them as distrustful and suspicious as well. Narcissistic individuals believed that others must have thought they were cool and special, whereas others actually perceived them as grandiose and exploitative (Oltmanns \& Turkheimer, 2006).

Applying this finding to PI, it seems likely that people exhibiting considerable anger and paranoia will be lower in PI than others; similarly, those with a "cool to be me" attitude may be low in PI - not recognizing that others see them as exploitative and grandiose. By contrast, people with relatively accurate self-knowledge may suffer, at times, from higher rates of anxiety and depressive disorders - recalling Freud's wry question of why people had to be depressed in order to see themselves clearly (cited in Appelbaum, 1973, p. 36). Because other PI skills predict well-being, it remains a challenge to understand how high PI individuals may be both higher in well-being and yet more prone to depression. Recognizing Personality-Relevant Information in Others: the Good Judge

A further research area relevant to perceiving personality examines "good judges" - those who are better than most at evaluating others' personality (Funder, 1995). Good judges possess certain (unspecified) cognitive abilities, coupled with extensive experience with other people. Initially, such individuals were viewed simply as extraverted (Akert \& Panter, 1988; Funder, 1995, 1999). More recently, such judges have been viewed as more interested in others regardless of extraversion-introversion. For example, people who reach out to others so as to feel better themselves (i.e., repair their own moods) may exhibit enhanced judgment of others as well (Gray \& Ambadi, 2008). Good judges also may possess higher general intelligence and greater openness to experience than others (Christiansen, Wolcott-Burnam, \& Janovics, 2005).

\section{Models of the Self: Self-Knowledge of Abilities}

\section{Forming Accurate Models of Personality}

The second broad skill area of personal intelligence involves forming accurate models of the self and others. People typically have accurate impressions of their abilities in areas where performance criteria are clear, simple, and readily observable, such as athletic fitness (e.g., how many sit-ups they can do), or the ability to be on time.

Many other kinds of abilities, however, such as writing clear prose, making a logical argument, or playing a violin with skill involve multiple, complex criteria for success. In these instances, only people competent in a given area of performance 
understand their true ability. That is, a minimum level of competence is necessary to know how to accurately appraise one's own and others' behaviors in a given area (Dunning, 2005, p. 161). Those who lack competence will be unable to understand whether they meet criteria of good performance or not; lacking competence, they will lack the necessary clues as to whether their actual performance deviates from what is desirable (Kruger \& Dunning, 1999).

Additional indicators of accurate self-knowledge emerge from how people seek information about themselves. Consider requests for feedback: some people ask leading questions so as to confirm their identity, e.g., "I'm a pretty good singer, aren't I?", or if depressed, "You think I'm a bad friend, don't you?". Other people obtain more accurate feedback by asking more problem-centered questions, such as: "I am interested in developing my singing; how do you think I could improve?". At work, managers who seek out unbiased information with questions such as - "How can I improve at this job? (Please feel free to criticize my present practice)" - have a higher openness to selfimprovement and end up being held in higher esteem by their subordinates, coworkers and superiors (Ashford \& Tsui, 1991; Tuckey, Brewer, \& Williamson, 2002).

People with better self-understanding also may employ various cognitive tricks (heuristics) to improve their self-estimations. For instance, people who simply make a schedule to complete a task often fail to accurately forecast how long a task might take. By contrast, the high PI individual may base her forecast on how long a similar task took her in the past. A second such trick is to, first, predict how long others would take, and then compare oneself to the average, understanding that each of us behaves like the average person much of the time (Dunning, 2005, p. 167). Many more such examples abound (Dunning, 2005, p. 165; Heath, Larrick, \& Klayman, 1998).

Dunning (2005, p. 163-164) has provided a helpful list of cues that are nondiagnostic and even misleading in evaluating someone's overall accurate knowledge of their ability. He reminds us that because developing accurate self-estimates in every sphere "... is a horribly thorny task," failures to know oneself in one area or another does not, by itself, reflect a person's overall lack of self-knowledge. Similarly, overconfident or even conceited self-views in a specific realm do not necessarily indicate a lack of selfknowledge overall; rather, these are fairly normal.

Translating these ideas to PI's expression, people high in PI must be competent in a complex, sophisticated skill area before claiming high self-knowledge about their own performance. Second, people higher in self-knowledge typically ask for feedback with neutral, problem-centered questions that convey an openness to hearing a range of potential responses. Third, people's use of cognitive tricks to adjust their selfimpressions or future predictions may be a sign of PI. Finally, modestly over-inflated self-regard and occasional lapses in self-knowledge are not diagnostic of PI or its absence.

\section{Models of Others: the Example of the Good Actor}

Good professional actors may reflect high PI in being able to master a character and then portray the role well. Wilson (2002, p. 197) suggested that although those entering the acting field may begin as extraverts, with some tendencies toward impulsiveness and exhibitionism, as actors mature in their profession their dominant traits become private self-consciousness and greater sensitivity to the expressive behavior of others. Actors also may possess somewhat more diffuse identities than others, in part, 
perhaps, as a consequence of their trying on (and being rewarded) for portraying different characters (Wilson, 2002, p. 191). Actors were inconsistent in this regard, however, with some actors feeling possessed by their characters, and others relatively unchanged by playing them.

In terms of skill development, actors, playwrights, and dramatists all rely on an imaginative involvement in the mind of the character(s) they portray (Wilson, 2002, pp. 65-71); playwrights and dramatists in particular empathize serially with the different characters they write about, shifting from one to another (Wilson, 2002, p. 49). All three groups also keep in mind how an audience will respond to them (in the case of actors) or respond to their works (in the case of playwrights).

In a review of motivational research on writers (both professional and otherwise) Kellogg (1994, p. 103) emphasized the contributions both of general intelligence, but also of the meaning-making that writing brings with it. According to Kellogg, making meaning defines human beings and writing provides a means for such meaning-making.

These observations suggest that a key contribution of the study of actors and writers (for this purpose) is to highlight their capacity to empathize with various different characters, their tendency to carefully observe the mannerisms and expressions of others, and their willingness to use writing, for example, as a method of meaning-making in one's life.

\section{Guiding Choices with} Accurate Personal Information

\section{Matching One's Personality to the Environment}

The third broad area of PI reviewed here involves using personal information to guide one's choices. For example, those who can match their own personality to the congruent demands of situations may do better in those environments than others - be those environments momentary such as choosing a ride in an amusement park, or longerterm such as a choice of occupation or marriage. People may choose housing, as one example, by considering which residents of an apartment complex or neighborhood are most similar to them (Niedenthal et al., 1985). Considerable research on marital success indicates that people match their personality to those they marry (Buss, 1985; Caspi, Herbener, \& Ozer, 1992). The similarity between members of a couple predicts happier and longer marriages - although here the findings are not quite as consistent (e.g., Acitelli, Douvan, \& Veroff, 1993; Buss, 1985; Caspi et al., 1992; Gonzaga, Campos, \& Bradbury, 2007). More consistent evidence exists that people are happier on the job if they can find a career that employs others much like themselves (Gottfredson \& Holland, 1990).

Although most research today has focused on a person's close fit with a given context, there likely are times when it makes sense to be different: for example, to celebrate differences between oneself and others (O'Connell, 2008; Plester \& Sayers, 2007), or to stand out, as in one's commitment to an unpopular view or creative idea (e.g., Hackley \& Kover, 2007). Personal intelligence may help in choosing the moments when such differences and unpopular commitments are more important than fitting in.

People also apply their general knowledge about personality so as to predict more generally who will be successful at marriage or at an occupation. For example, choosing someone with more positive emotional traits, more traditional values, and the desire to 
avoid harm, promotes marital stability (McGue \& Lykken, 1992). If a stable marriage is one's goal, then selecting partners with such qualities also may indicate higher PI.

Translating such ideas to expressive markers of PI, one sign of higher personal intelligence is a good fit between an individual's characteristics and their chosen environment in several key areas of a person's life. This would include a good fit with one's career, with significant people such as one's friends and spouse, and a good fit in other, sometimes less crucial areas such as choices of where to live, and type of housing. Understanding Developmental Trajectories

Another area in which a person guides his or her own choices is in planning for the future. This includes ordering life tasks so as to be congruent with personal biosocial and occupational clocks. Among women, for example, skill at planning when to have and rear children, and at juggling such traditional roles with career demands (if desired), may be an important determinant of well-being later in life (e.g., Helson \& McCabe, 1994).

Altering the specifics of one's personality over time also can enhance personal performance. For example, staying in school, cultivating openness and conscientiousness, and managing anxiety all may contribute to intellectual growth (Chamorro-Premuzic \& Furnham, 2006; Gustafsson, 2008). Returning to issues of timing, both women and men take approximately 10 years to develop expertise in such specific work areas as music composition, mathematics, and law (Ericsson \& Lehmann, 1996; Kaufman \& Kaufman, 2007; Simon \& Chase, 1973; Simonton, 1994).

Higher PI individuals are more likely to apply such information to their own and others' life planning. Regarding skill-development, for example, a person who seeks expertise and allocates the time necessary to attain it would exhibit a higher degree of PI relative to someone who doesn't take such requirements into account.

Systematizing Goals, Plans, and Life Stories

\section{The Good Motivation Systematizer}

The final area of personal intelligence examined here involves systematizing one's motivations, plans and autobiography. In the area of motivation, this involves selecting goals that are consistent (as opposed to conflicting) with one another, and choosing aims and objectives that are realistic given one's talents and resources. Doing so increases one's well-being (Cox \& Klinger, 2004; Emmons \& King, 1988). For example, a person who holds two goals such as "being honest with myself and others," and "appearing smarter than I am," will face considerable (and self-inflicted) goal conflicts. The aim of "being honest," may violate many social norms of politeness and create considerable conflict on its own; it also conflicts with the second goal, (to appear "smarter than I am") that involves disguising one's honest belief (Emmons \& King, 1988). Translating this to observable expressions, the individual higher in PI should exhibit goals that are more consistent with one another relative to other people.

Systematizing and Using Autobiographical Experiences

A high PI individual also can draw on his or her personal memories and autobiography for self-direction. Some people report recalling autobiographical events so as to motivate themselves and to learn from past mistakes, as well as to develop their identities (Bluck, Alea, Habermas, \& Rubin, 2005, p. 104; Pillemer, 1998). For example, Michael Jordan, the basketball player, intentionally recalls failing to make a sports team 
in high school when he wants to motivate himself to work harder in his current life (Pillemer, 1998).

The Good Autobiographical Story Teller

Reasoning about their autobiography also helps individuals define themselves more generally (Bluck et al., 2005; Pillemer, 2003). As people recall their life experiences, they may take the opportunity to systematize their goals, plans, and autobiographical stories so as to create a personal sense of coherency and meaning from their lives (Erikson, 1963; Frank1, 1963; McAdams, 2006). People recall events to see if their "...beliefs or values have changed..." and to understand, "who I am now" (Bluck et al., 2005, p. 104) as well as to find meaning in their pursuits and life stories. This meaning typically involves a sense of generating something to help the next generation, be it rearing a family or producing work to assist other people (Erikson, 1963). For example, in the United States, narrative life stories often take the form of finding redemption through helping others (McAdams, 2006). The discovery of such meaning is central to psychological well-being (Frankl, 1963). These skills have been characterized as possessing intelligence-like properties (Pillemer, 1998, p. 211).

Applying such observations suggests two further indicators of PI expressions. First, higher PI people would be more likely to describe memories they employ to motivate themselves relative to others, and second, higher PI individuals would be more likely to tell life stories with a plot or theme that reveals a meaning to themselves and others.

\section{Summary of Descriptions of Personal Intelligence}

The above review collected a number of features that might indicate high personal intelligence (or its absence). Some features reflective of PI are likely to be expressed across people in relatively invariant ways: being motivated to understand others, observing others carefully, using an open style in requesting feedback, and appreciating the time involved in meeting life-span tasks are examples. Other expressions of PI are tailored to an individual's specific psychological characteristics - such as using personal memories to motivate oneself and creating an accurate self-concept. Still other features will be sensitive to social contexts. An example is doing well in psychotherapy because psychotherapy is more available (and acceptable) in some cultures than others.

It is true that any PI feature of Table 2, taken individually, could have arisen from a psychological source aside from PI. For example, the use of a motivating memory might reflect a person's high level of motivation, independent of any personal intelligence. For that reason, any single feature is likely to be insufficient to indicate the presence or absence of high personal intelligence. When the features are employed as a group, however, they are likely to be powerful predictors for use in identifying people high and low in PI.

That is, though each individual feature in Table 2 might be low in reliability and validity, when combined into a group, their reliability and validity will be far higher because the error variance component will tend to cancel out across items and their true score variance will accumulate (Nunnally, 1978). Collectively, therefore, the features are likely to indicate who is high and low in PI, and represent a reasonable depiction of what a person high or low in PI might be like. Modified just slightly, the content of Table 2 could form the basis for a classification system to identify those high and low in PI based 
on peoples' expressions of the ability. Both the "look" of high and low PI and the use of such a coding system in future research will be considered in the Discussion.

\section{DISCUSSION}

The Emergence of Personal Intelligence and Its Scope

Twentieth century research on the intelligences centered on the "cool intelligences" - intelligences that pertained to relatively impersonal cognitive information. Examples of these included verbal-comprehension, perceptualorganizational, and similar intelligences. Late in the $20^{\text {th }}$ century, however, research activity began to focus on a contrasting, "hot" group including the emotional and social intelligences. These hot intelligences pertained to matters of personal significance such one's own emotions and the behavior of those in one's surrounding situations, relationships, and social networks.

The hot intelligences form an interrelated set that collectively cover a wide range of personal concerns. Social intelligence, for example, pertains to interpersonal interactions, intimacy, power relations, and the effects of groups on the individual. Emotional intelligence pertains to emotions and emotional facilitation of thought. What has been less elucidated is an intelligence pertaining to personality and its processes. Personal intelligence as described here pertains to recognizing one's motives, goals, and feelings, forming accurate self- and other-concepts, using such knowledge in decision making, and constructing a life story more generally.

The Expression of Personal Intelligence

Understanding PI's expression is necessary to establishing systems for recognizing PI ability in individuals and groups, as well as for appreciating its impact on a person's life. The present article has developed a picture of PI's expression by reviewing contemporary research on the mental abilities that make up PI and examining its precursor concepts as well. Expressions of these abilities and precursors were elaborated and then summarized in Table 2. Together, the contents of the review provide a tentative first look at such expressions.

High PI individuals express their abilities in many ways. They appear motivated to know themselves and others, exhibit expertise in one or more occupational areas and understand their own skills in those areas. Moreover, they fit themselves well into situations and choose better longer term environments for themselves than do others. High PI individuals pursue goals that are mostly consistent with one another, use their personal memories to motivate themselves, and go on more generally to create a wellunderstood personal identity. That identity often includes the pursuit of personallyimportant, societally-meaningful activities.

Such individuals also may suffer from certain vulnerabilities. For example, their openness to criticism and self-understanding may render them vulnerable to dysthymia or depression at times, although, given their psychological mindedness, they may be more responsive than others to insight-oriented psychotherapy such as psychodynamic and cognitive-behavioral therapies.

Low PI individuals, by contrast, appear relatively out-of-touch with their inner states - as well as out-of-touch with how others view them. They may develop self 
concepts that are relatively undifferentiated and even inaccurate, and such individuals may fail to take into account other's personalities and personal preferences when interacting with them. These low PI individuals' goals may appear scattered or in conflict, and their life course may appear to lack coherence in some or most of its aspects. It also is the case that each person's abilities are varied, and a person can compensate for less-than-optimal qualities in PI by developing compensatory abilities in another.

Where societies allow for it, people higher in PI may be able to form a better social contract than otherwise - choosing better occupations, life relationships, activities, and other outcomes for themselves. By doing so, they may, in comparison with those lower in PI, better meet the demands of society, contribute to society, and also meet their own needs.

\section{Envisioning Future Research in Personal Intelligence}

The study of the mental reasoning that makes up PI, on the one hand, and the expression of PI, on the other, concern two distinct, related research projects. Mostly, the two aspects of PI will be related; that is, a person with high PI will choose to employ it and its use will be expressed; an individual with low PI will display it less. Yet a person with high PI might choose not to apply it if, for example, their interests or environment promoted other goals such as climbing out of poverty to the relative exclusion of personal development. Moreover, some people who are relatively low in PI might appear to possess it through, for example, having friends who guide them in major life decisions.

Personal intelligence as a mental ability and its expression, therefore, must be assessed by separate methods. The inner capacity - PI as mental ability - is most validly measured via ability-based psychological tests - the gold standard of the intelligences (Mayer et al., 2008). The expression of PI, on the other hand, requires other methods.

At present, there are few or no readily-accessible criteria for identifying the expression of PI. This is in marked contrast to the resources available for assessing the expression of cool intelligences. Entire institutions, such as educational systems, are centered around promoting and assessing such cool intelligences as verbalcomprehension intelligence. Schools employ testing, grades, SATs, status of the educational institution, and the like as potential correlates of the ability (Mayer, Salovey, Caruso, \& Sitarenios, 2001).

In contrast, society provides few or no ready criteria for the hot intelligences. Personal intelligence, however, ought to be possible to discern in the context of an individual's life choices because personality itself is manifest in the contours of an individual's life (e.g., Alexander, 1990; Runyan, 1988; Schultz, 2005). Understanding the expression of PI can, in turn, provide insight into the significance of the ability, and can add to an understanding of those who might or might not possess it. For example, if it turns out that high PI individuals often become writers, actors and therapists, such observations can serve to test the validity of mental-ability measures of PI.

From the list of high PI features developed here, a first set of criteria can be created according to which PI's expression can be indexed. For example, such features could be converted into a biographical coding system so as to evaluate a person's PIrelated characteristics from the events and construals of their life: personal intelligence may lend itself to such evaluations because one's life style and biography are, in some sense, a record of the operation of personality (and PI) in interaction over time with the 
environment. The next step, from Table 2, in other words, is to develop such coding systems as distinct entities and to evaluate their validity as assessment techniques. The precise methods for doing this deserve due consideration in future treatments. For now, this initial examination of what PI expressions are like can serve as a basis for such future work.

The full spectrum and significance of the hot intelligences is now more fully apparent than before. This description of the likely characteristics of individuals high in personal intelligence - preliminary though it may be - can contribute to an understanding of this group of abilities. If PI skills exist as a coherent and interrelated group, then it may further be the case that teaching general knowledge about personality may enhance peoples' abilities to use whatever level of skills they possess, to the broader benefit of society. That, however, must await advances in a nearer-term phase of research on personal intelligence - which should focus on assessment of the intelligence and its correlates. The present investigation of personal intelligence and its expression provides one potential basis for the development of new methods for identifying those high and low in personal intelligence, hastening the next phases of research on the topic. 


\section{References}

Acitelli, L. K., Douvan, E., \& Veroff, J. (1993). Perceptions of conflict in the first year of marriage: How important are similarity and understanding? Journal of Social and Personal Relationships, 10, 5-19.

Akert, R. M., \& Panter, A. T. (1988). Extraversion and the ability to decode nonverbal communication. Personality and Individual Differences, 9, 965-972.

Alexander, I. (1990). Personology: Method and content in personality assessment and psychobiography. Durham, NC: Duke University Press.

Anonymous. (February 27, 1851). General Jackson and the Clerk;. New Hampshire Patriot \& State Gazette, p. 4,

Appelbaum, S. A. (1973). Psychological-mindedness: Word, concept and essence. International Journal of Psycho-Analysis, 54, 35-46.

Ashford, S. J., \& Tsui, A. S. (1991). Self-regulation for managerial effectiveness: The role of active feedback seeking. . Academy of Management Journal, 34, 251-280.

Baron-Cohen, S. (1995). Mindblindness: An essay on autism and theory of mind. Cambridge, MA: MIT Press.

Baumeister, R. F., Campbell, J. D., \& Krueger, J. I. (2003). Does high self-esteem cause better performance, interpersonal success, happiness, or healthier lifestyles? Psychological Science in the Public Interest, 4, 1-44.

Bluck, S., Alea, N., Habermas, T., \& Rubin, D. C. (2005). A tale of three functions: The self-reported uses of autobiographical memory. Social Cognition, 23, 91-117.

Buss, D. M. (1985). Human mate selection. American Scientist, 73, 47-51.

Buss, D. M. (1991). Evolutionary personality psychology. Annual Review of Psychology, 42, 459-491.

Buss, D. M. (2001). Human nature and culture: An evolutionary psychological perspective. Journal of Personality, 69, 955-978.

Carroll, J. B. (1993). Human cognitive abilities: A survey of factor analytic studies. New York: Cambridge University Press.

Carton, J. S., Kessler, E. A., \& Pape, C. L. (1999). Nonverbal decoding skills and relationship well-being in adults. Journal of Nonverbal Behavior, 23, 91-100.

Caspi, A., Herbener, E. S., \& Ozer, D. J. (1992). Shared experiences and the similarities of personalities: A longitudinal study of married couples. Journal of Personality and Social Psychology, 62, 281-291.

Ceci, S. J., \& Williams, W. M. (Eds.). (2007). Why aren't more women in science: Top researchers debate the evidence. Washington, DC: American Psychological Association.

Cervone, D. (2005). Personality Architecture: Within-Person Structures and Processes. Annual Review of Psychology, 56, 423-452.

Chamorro-Premuzic, T., \& Furnham, A. (2006). Intellectual competence and intelligent personality: A third way in differential psychology. Review of General Psychology, 10, 251-267.

Christiansen, N. D., Wolcott-Burnam, S., \& Janovics, J. E. (2005). The good judge revisited: Individual differences in the accuracy of personality judgments. Human Performance, 18, 123-149.

Cox, W. M., \& Klinger, E. (2004). Handbook of motivational counseling: Concepts, approaches, and assessment. New York: John Wiley \& Sons. 
Cunningham, C. (2005). A certain and reasoned art: Character education in America. In D. K. Lapsley \& F. C. Power (Eds.), Character psychology and character education. Notre Dame, IN: Notre Dame Press.

Dunbar, R. I. M. (2003). The social brain: Mind, language, and society in evolutionary perspective. Annual Review of Anthropology, 32, 163-181.

Dunning, D. (2005). Self-insight: Roadblocks and detours on the path to knowing thyself. New York, NY: Psychology Press.

Elfenbein, H. A., Der Foo, M. D., White, J., \& Tan, H. H. (2007). Reading your counterpart: The benefit of emotion recognition accuracy for effectiveness in negotiation. Journal of Nonverbal Behavior.

Emmons, R. A., \& King, L. A. (1988). Conflict among personal strivings: Immediate and long-term implications for psychological and physical well-being. Journal of Personality and Social Psychology, 54, 1040-1048.

Ericsson, K. A. (2007). An expert-performance perspective of research on medical expertise: The study of clinical performance. Medical Education, 41, 1124-1130.

Ericsson, K. A., \& Lehmann, A. C. (1996). Expert and exceptional performance: Evidence of maximal adaptation to task constraints. Annual Review of Psychology, 47, 273-305.

Erikson, E. H. (1963). Childhood and society (2nd ed.). New York: W. W. Norton and Company.

Farber, B. A., \& Golden, V. (1997). Psychological mindedness in psychotherapists. In M. McCallum \& W. E. Piper (Eds.), Psychological mindedness: A contemporary understanding (pp. 211-235). Mahwah, NJ: Lawrence Erlbaum Associates.

Frankl, V. E. (1963). Man's search for meaning: An introduction to logotherapy. Oxford, England: Washington Square Press.

Friedman, N. P., Miyake, A., Corley, R. P., Young, S. E., DeFries, J. C., \& Hewitt, J. K. (2006). Not All Executive Functions Are Related to Intelligence. Psychological Science, 17, 172-179.

Funder, D. C. (1995). On the accuracy of personality judgment: A realistic approach. Psychological Review, 102, 652-670.

Funder, D. C. (1999). Personality judgment: A realistic approach to person perception. San Diego, CA: Academic Press.

Funder, D. C. (2006). Towards a resolution of the personality triad: Persons, situations, and behaviors. Journal of Research in Personality, 40, 21-34.

Galotti, K. M. (2001). Helps and hindrances for adolescents making important real-life decisions. Journal of Applied Developmental Psychology, 22, 275-287.

Gardner, H. (1983). Frames of mind: The theory of multiple intelligences. New York: Basic Books.

Gardner, H. (1993). Frames of mind: The theory of multiple intelligences (10th Anniversary Edition ed.). New York: Basic Books.

Gonzaga, G. C., Campos, B., \& Bradbury, T. (2007). Similarity, convergence, and relationship satisfaction in dating and married couples. Journal of Personality and Social Psychology, 93, 34-48.

Gottfredson, G. D., \& Holland, J. L. (1990). A longitudinal test of the influence of congruence: Job satisfaction, competency utilization, and couterproductive behavior. Journal of Counseling Psychology, 27, 389-398. 
Guernsey, A. H. (July 1857). Editor's table. Harper's New Monthly Magazine.

Gustafsson, J.-E. (2008). Schooling and intelligence: Effects of track of study on level and profile of cognitive abilities. In P. C. Kyllonen, R. D. Roberts \& L. Stankov (Eds.), Extending intelligence: Enhancement and new constructs (pp. 37-59). New York: Lawrence Erlbaum/Taylor \& Francis Group.

Hackley, C., \& Kover, A. J. (2007). The trouble with creatives: Negotiating creative identity in advertising agencies. International Journal of Advertising, 26, 63-78.

Heath, C., Larrick, R. P., \& Klayman, J. (1998). Cognitive repairs: How organizational practices can compensate for individual shortcomings. Research in organizational behavior: An annual series of analytical essays and critical reviews, 20, 1-37.

Helson, R., \& McCabe, L. (1994). The social clock project in middle age. In B. F. Turner \& L. E. Troll (Eds.), Women growing older: Psychological perspectives (pp. 6893). Thousand Oaks, CA: Sage Publications.

Higgins, E. T. (1987). Self-discrepancy theory: A theory relating self and affect. Psychological Review, 94, 319-340.

Holland, J. L., \& Holland, J., E. (1978). Distributions of personalities within occupations and fields of study. Vocational Guidance Quarterly, 25, 226-231.

Kaufman, S. B., \& Kaufman, J. C. (2007). Ten years to expertise, many more to greatness: An investigation of modern writers. Journal of Creative Behavior, 41, 114-124.

Kellogg, R. T. (1994). The psychology of writing. New York: Oxford University Press.

Kenrick, D. T., \& Funder, D. C. (1988). Profiting from controversy: Lessons from the person-situation debate. American Psychologist, 43, 23-34.

Kincaid, H. (2002). Social sciences. In P. Machamer \& M. Silberstein (Eds.), The Blackwell guide to the philosophy of science (pp. 290-311). Malden, MA: Blackwell.

Kruger, J., \& Dunning, D. (1999). Unskilled and unaware of it: How difficulties in recognizing one's own incompetence lead to inflated self-assessments. Journal of Personality and Social Psychology, 77, 1121-1134.

Lubinski, D., Webb, R. M., \& Morelock, M. J. (2001). Top 1 in 10,000: A 10-year follow-up of the profoundly gifted. Journal of Applied Psychology, 86, 718-729.

Markus, H., \& Nurius, P. (1986). Possible selves. American Psychologist, 41, 954-969.

Matarazzo, J. D. (1972). Wechsler's measurement and appraisal of adult intelligence (5th ed.). New York: Oxford University Press.

Matsumoto, D., LeRoux, J., \& Wilson-Cohn, C. (2000). A new test to measure emotion recognition ability: Matsumoto and Ekman's Japanese and Caucasian Brief Affect Recognition Test (JACBART). Journal of Nonverbal Behavior, 24, 179-209.

Matsumoto, D., LeRoux, J. A., Bernhard, R., \& Gray, H. (2004). Unraveling the psychological correlates of intercultural adjustment potential. International Journal of Intercultural Relations, 28, 281-309.

Mayer, J. D. (2005). A tale of two visions: Can a new view of personality help integrate psychology? American Psychologist, 60, 294-307.

Mayer, J. D. (2008). Personal intelligence. Imagination, Cognition \& Personality, 27, 209-232.

Mayer, J. D., Roberts, R. D., \& Barsade, S. G. (2008). Human abilities: Emotional intelligence. Annual Review of Psychology, 59, 507-536. 
Mayer, J. D., Salovey, P., \& Caruso, D. R. (2008). Emotional intelligence: New ability or eclectic traits? American Psychologist, 63, 000-000.

Mayer, J. D., Salovey, P., Caruso, D. R., \& Sitarenios, G. (2001). Emotional intelligence as a standard intelligence. Emotion, 1, 232-242.

McAdams, D. P. (2006). The Redemptive Self. New York: Oxford University Press.

McAdams, D. P. (2006). The redemptive self: Stories Americans live by. New York, NY: Oxford University Press.

McAdams, D. P., \& Pals, J. L. (2006). A new Big Five: Fundamental principles for an integrative science of personality. American Psychologist, 61, 204-217.

McCallum, M., \& Piper, W. E. (Eds.). (1997). Psychological mindedness: A contemporary understanding. Mahway, NJ: Lawrence Erlbaum Associates, Inc.

McCrae, R. R., \& Costa, P. T., Jr. (1999). A five-factor theory of personality. In L. A. Pervin \& O. P. John (Eds.), Handbook of Personality: Theory and Research (2nd ed.). New York/London: The Guilford Press.

McGue, M., \& Lykken, D. T. (1992). Genetic influence on risk of divorce. Psychological Science, 6, 368-373.

Mischel, W. (1968). Personality and assessment. New York: John Wiley \& Sons.

Mischel, W. (2004). Toward an integrative science of the person. Annual Review of Psychology, 55, 1-22.

Niedenthal, P. M., Cantor, N., \& Kihlstrom, J. F. (1985). Prototype matching: A strategy for social decision making. Journal of Personality and Social Psychology, 48, 575-584.

Nowicki, S., \& Carton, J. (1993). The measurement of emotional intensity from facial expressions. Journal of Social Psychology, 133, 749-750.

Nunnally, J. C. (1978). Psychometric theory. New York: McGraw-Hill.

O'Connell, M. (2008). The marriage benefit. New York: Springboard Press.

Oltmanns, T. F., \& Turkheimer, E. (2006). Perceptions of Self and Others Regarding Pathological Personality Traits. In R. F. Krueger \& J. L. Tackett (Eds.), Personality and psychopathology (pp. 71-111). New York, NY: Guilford Press.

Pelham, B. W., Mirenberg, M. C., \& Jones, J. T. (2002). Why Susie sells seashells by the seashore: Implicit egotism and major life decisions. Journal of Personality and Social Psychology, 82, 469-487.

Perkins, D., Tishman, S., Ritchhart, R., Donis, K., \& Andrade, A. (2000). Intelligence in the wild: A dispositional view of intellectual traits. Educational Psychology Review, 12, 269-693.

Pillemer, D. B. (1998). Momentous events, vivid memories. Cambridge, MA: Harvard University Press.

Pillemer, D. B. (2003). Directive functions of autobiographical memory: The guiding power of the specific episode. Memory, 11, 193-202.

Plester, B. A., \& Sayers, J. (2007). 'Taking the piss': Functions of banter in the IT industry. Humor: International Journal of Humor Research, 20, 157-187.

Roberts, B. W., Kuncel, N. R., Shiner, R., Caspi, A., \& Goldberg, L. R. (2007). The power of personality: The comparative validity of personality traits, socioeconomic status, and cognitive ability for predicting important life outcomes. Perspectives on Psychological Science, 2, 313-345. 
Rubin, R. S., Munz, D. C., \& Bommer, W. H. (2005). Leading from within: The effects of emotion recognition and personality on transformational leadership behavior. Academy of Management Journal, 48, 845-858.

Runyan, W. M. (1988). Progress in psychobiography. Journal of Personality 56, 295-326.

Salovey, P., \& Grewal, D. (2005). The science of emotional intelligence. Current Directions in Psychological Science, 14, 281-285.

Schultz, W. T. (2005). How to strike psychological pay dirt in biographical data. In W. T. Schultz (Ed.), Handbook of psychobiography (pp. 42-63). New York: Oxford University Press.

Simon, H. A., \& Chase, W. G. (1973). Skill in chess. American Scientist, 61, 394-403.

Simonton, D. K. (1994). Greatness. New York: Guilford.

Sloan, T. S. (1983). The aura of projected personal futures: A neglected aspect of major life decisions. Personality and Social Psychology Bulletin, 9, 559-566.

Sternberg, R. J. (2007). Who are the bright children? The cultural context of being and acting intelligent. Educational Researcher, 36, 148-155.

Sternberg, R. J., \& Detterman, D. R. (1986). What is intelligence? Norwood, NJ: Ablex.

Tuckey, M., Brewer, N., \& Williamson, P. (2002). The influence of motives and goal orientation on feedback seeking. Journal of Occupational and Organizational Psychology, 75, 195-216.

Twenge, J. M. (2006). Generation me: Why today's young Americans are more confident, assertive, entitled -- and more miserable than ever before. New York: Free Press.

Walker, R. E., \& Foley, J. M. (1973). Social intelligence: Its history and measurement. Psychological Reports, 33, 839-864.

Wechsler, D. (1997). WAIS III: Wechsler Adult Intelligence Scale (Third ed.). San Antonio, TX: The Psychological Corporation.

Wilson, G. D. (2002). Psychology for performing artists. Philadelphia: Whurr. 